\title{
Characterization of Chemical And Physical Properties of Palm Fibers
}

\author{
Pradeep, P. ${ }^{1}$ and Edwin Raja Dhas, J. ${ }^{2}$ \\ ${ }^{1}$ Department of Mechanical Engineering, Noorul Islam University, Kumaracoil, Tamil \\ Nadu, India \\ ${ }^{2}$ Department of Automobile Engineering, Noorul Islam University, Kumaracoil, Tamil \\ Nadu, India
}

\begin{abstract}
Natural fibers like palm fibers provides new hope for researchers to compete with hazardous synthetic fibers with its excellent chemical and physical properties This work investigates the extraction of various fibers that are available from various portions of the palm tree and to characterize its chemical and physical properties. Also the results were compared with other natural fibers.
\end{abstract}

\section{KEYWORDS}

Natural fiber, palm, coir, chemical properties, physical properties.

\section{INTRODUCTION}

Natural fibers were obtained by nature from plants (stems, leaves, roots, fruits and seeds, etc).Efforts has been taken to use natural fibers as reinforcements in polymer composites from very olden days. [1-4].These fibers offer the potential to act as reinforcement for low to medium strength applications such as automotive, sporting goods, marine, electrical, industrial, etc. Over the past few decades, natural fibers received much attention from the research community. Natural fibers are replacing glass fibers for fabricating composite materials [5-7]. Investigations on the mechanical properties of composite materials reinforced with several natural fibers were studied. These studies include palm, kenaf, jute, hemp, flax, bamboo, etc [8-14]. Palm fiber is a natural fiber obtained from various portions of Palm tree (Borassus flabellifer), which is found in abundance in the southern parts of India. Characterization of plant fiber can be done based on its cellular structure. The chemical structure of natural fiber or plant fiber comprises of cellulose, hemicellulose, lignin, pectin and extraneous materials. Each cell of fiber comprises of crystalline cellulose regions (microfibrils) which are interconnected via hemicellulose and lignin fragments. [15-17].

In this paper we report the measured properties of fibers chosen from various parts of the palm tree and the compared results with other natural fibers. 


\section{MATERIALS ANDZ METHOD}

\subsection{Fiber extraction}

The palm fibers were available plenty from Kanyakumari District, Tamil Nadu, INDIA fibers from various parts of the palm tree were extracted by either by retting in water and/or by mechanical processing or hand picking. The fibers were cleaned with water after soaking for two weeks. The fibers were further dried in natural sunlight to remove moisture content and long uniform fibers were obtained (Fig. 1).

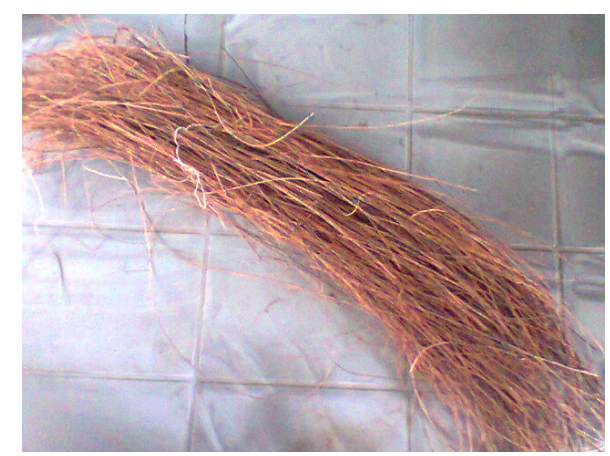

Palm leaf stalk fiber

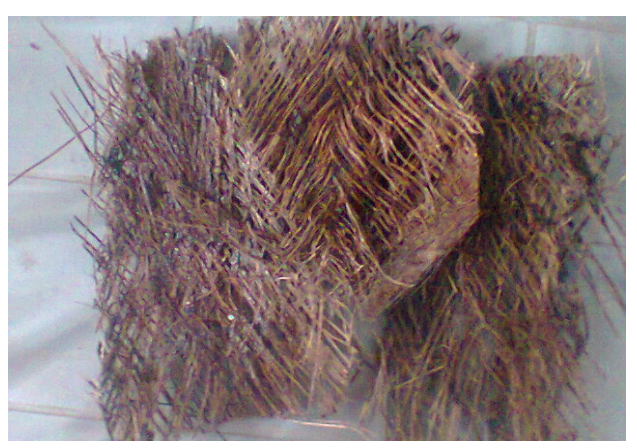

Palm leaf sheath fiber

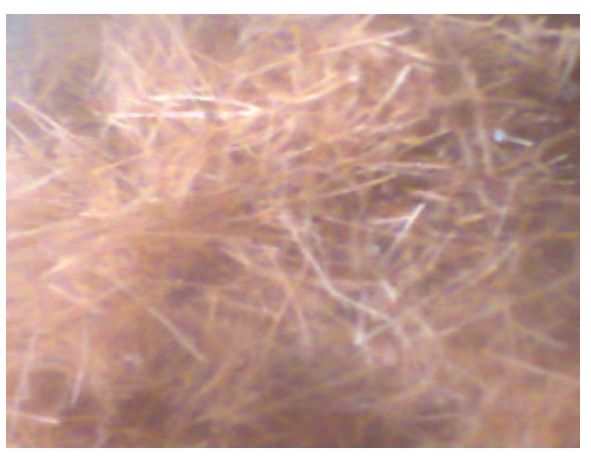

Palm fruit fiber

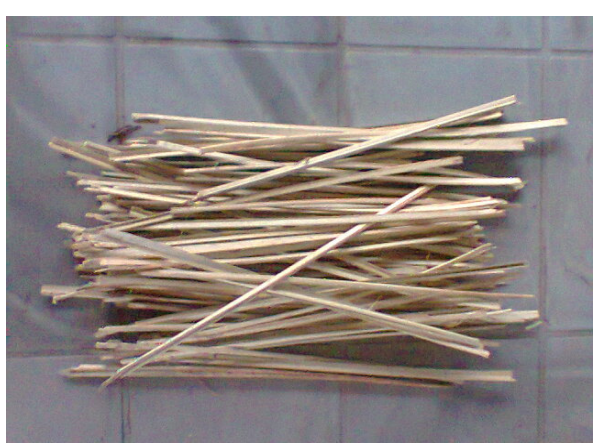

Palm petiole fiber

Figure 1. Extracted fibers from various portions of palm tree

\subsection{Testing Chemical properties}

Cellulose, hemi-cellulose, lignin affect the different properties of fibers while reinforcing. Also the rest moisture content in fibers have negative effects for reinforcement. To determine the moisture content the sample was dried in an oven at $104{ }^{\circ} \mathrm{C}$ for $4 \mathrm{hrs}$ and weighed in an electronic weighing machine The percentage of moisture present per unit weight of each variety of fiber is evaluated. 


\subsection{Testing Physical properties}

\subsubsection{Fiber density}

Using pycnometer having to line as density comparing element, the density of palm fibers was calculated using the relation:

$$
\rho_{\text {fiber }}=\left(\mathrm{m}_{2}-\mathrm{m}_{1}\right) /\left[\left(\mathrm{m}_{3}-\mathrm{m}_{1}\right)\left(\mathrm{m}_{4}-\mathrm{m}_{2}\right)\right] \rho_{\mathrm{t}}
$$

Where, $\rho_{\text {fiber }}$ is the density of palm fibers $(\mathrm{g} / \mathrm{cm} 3)$,

$\rho_{\mathrm{t}}$ is the density of toluene $(\mathrm{g} / \mathrm{cm} 3)$,

$\mathrm{m}_{1}$ is the mass of various elements used $(\mathrm{kg})$.

\subsubsection{Tensile strength of fibers}

The tensile test was conducted using INSTRON 5500Rtype UTM as per the ASTM D 3822-07 standard for all fibers. The fibers with gauge lengths of $20 \mathrm{~mm}, 30 \mathrm{~mm}, 40 \mathrm{~mm}$ and $50 \mathrm{~mm}$ were tested. A constant crosshead speed of $0.1 \mathrm{~mm} / \mathrm{min}$ was used for the testing. The test was conducted at (ambient temperature of $28{ }^{\circ} \mathrm{C}$ and R.H. of $65 \%$ ).

\section{RESULTS AND DISCUSSION}

The composition of cellulose, hemi-cellulose, density and strength of fiber varies with aging and the plantation environment. The properties of palm fiber in comparison with other natural fibers have been discussed in this chapter.

\subsection{Chemical properties}

Chemical analysis of palm fiber shows high cellulose content as seen from Table 1. The hemicellulose content is quite low when compared with other natural fibers. Cellulose content is responsible for long fiber chain that ranges $(28-53) \%$ for palm fibers. Hemi-cellulose leads to disintegration of cellulose microfibrils that decrease the fiber strength that ranges (12-43) \% for palm.

Table 1 Chemical properties of natural fibers in comparison with palm fibers

\begin{tabular}{|l|c|c|c|c|}
\hline \multirow{2}{*}{\multicolumn{1}{|c|}{ Fiber }} & \multicolumn{3}{|c|}{ Chemical properties } \\
\cline { 2 - 5 } & $\begin{array}{c}\text { Cellulose } \\
(\boldsymbol{\%})\end{array}$ & $\begin{array}{c}\text { Hemi cellulose } \\
(\boldsymbol{\%})\end{array}$ & $\begin{array}{c}\text { Lignin } \\
(\%)\end{array}$ & $\begin{array}{c}\text { Wax } \\
(\%)\end{array}$ \\
\hline Palm leaf stalk & $40-52$ & $42-43$ & - & - \\
Palm leaf sheath & 28 & 25 & 45 & - \\
Palm petiole & 30 & 14 & 28 & - \\
Palm fruit & 53 & 12 & 21 & 0.8 \\
Coir & $32-43$ & $0.15-0.25$ & $40-45$ & - \\
Pineapple leaf & $70-83$ & - & $5-12.7$ & - \\
\hline
\end{tabular}




\subsection{Physical properties}

The Physical properties of natural fibers in comparison with palm fibers were presented in the Table 2.

Table 2 Physical properties of natural fibers in comparison with palm fibers

\begin{tabular}{|l|c|c|c|c|}
\hline \multirow{2}{*}{ Fiber } & \multicolumn{4}{|c|}{ Physical properties } \\
\cline { 2 - 5 } & $\begin{array}{c}\text { Density } \\
\text { (g/cm3) }\end{array}$ & $\begin{array}{c}\text { Elongation } \\
(\mathbf{\%})\end{array}$ & $\begin{array}{c}\text { Tensile } \\
\text { strength } \\
\text { (MPa) }\end{array}$ & $\begin{array}{c}\text { Young's } \\
\text { modulus } \\
\text { (GPa) }\end{array}$ \\
\hline Palm leaf stalk & $1-1.2$ & $2-4.50$ & $97-196$ & $2.50-$ \\
Palm leaf sheath & $1.20-1.30$ & 2.84 & 220 & 4.8 \\
Palm petiole & $0.7-1.55$ & 25 & 248 & 3.24 \\
Palm fruit & 1.09 & 28 & 423 & $6 .-8$. \\
Coir & $1.15-1.2$ & 30 & 175 & $4 .-6$. \\
Pineapple leaf & $0.80-1.60$ & 14.5 & 144 & $400-627$ \\
\hline
\end{tabular}

\subsubsection{Fiber density.}

The investigated palm fibers was found to have an average density of $\left(0.7-1.55 \mathrm{~g} / \mathrm{cm}^{3}\right)$ which is significantly lower than widely used synthetic fibers such as E-glass fiber $\left(2.56 \mathrm{~g} / \mathrm{cm}^{3}\right)$ and carbon fiber(1.4-1.8 $\mathrm{g} / \mathrm{cm} 3)$. Figure 3 shows the density of few natural fibers.

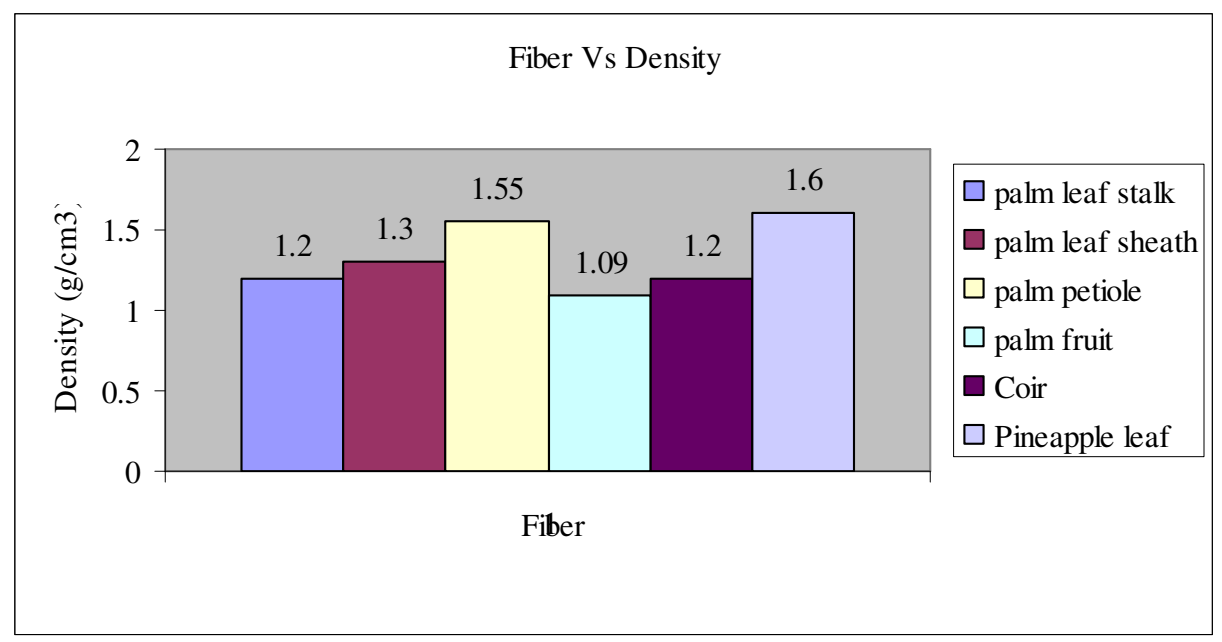

Figure 3 shows the density of palm fibers in comparison with other natural fibers. 


\subsubsection{Tensile strength}

Figure 4 shows the tensile strength of palm fibers and few natural fibers. The tensile behavior of the palm fibers increases with increase in gauge lengths from $10 \mathrm{~mm}$ to $40 \mathrm{~mm}$. As the gauge length increases the deviation from the mean value for various samples increases, which was expected for any natural fiber characterization. The variation in Young's modulus was rather high which is due to artifacts.

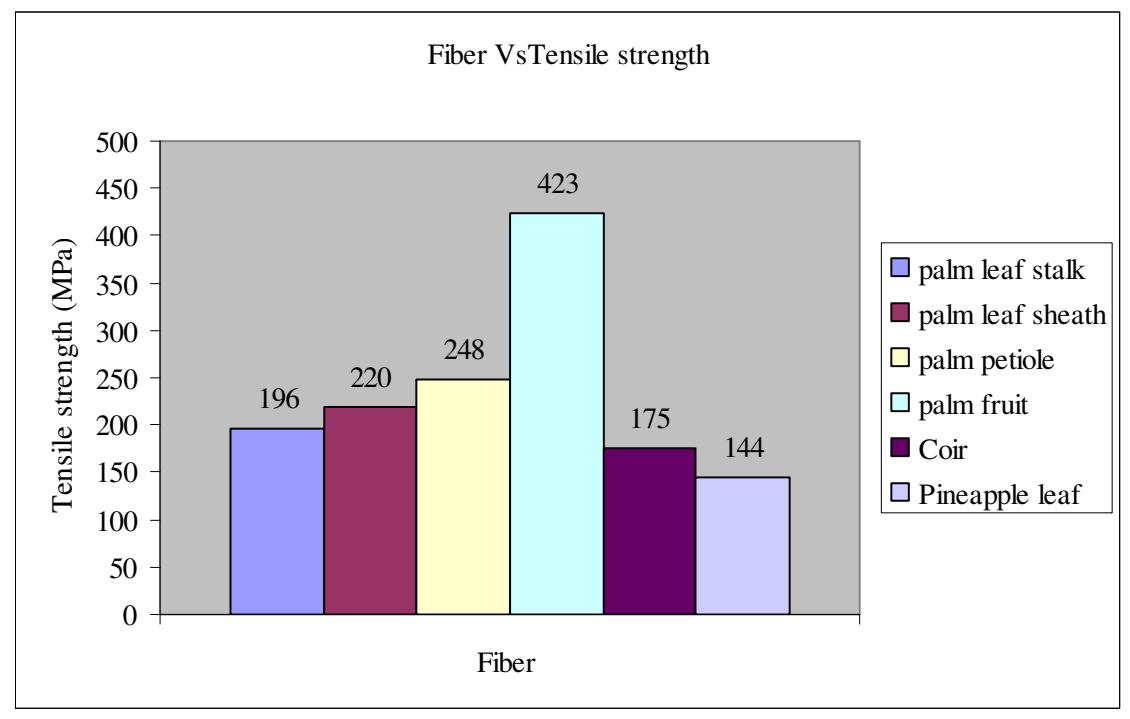

Figure 4 shows the Tensile strength of palm fibers and other natural fibers.

\section{CONCLUSION}

The characterization of palm fibers provides new hope for natural fiber research to compete with hazardous synthetic fiber with its excellent properties. The density of palm fibers is significantly lower than that of the popular glass fiber, carbon fiber, etc. and also gives $20 \%$ better specific strength. The tensile strength and Young's modulus was significantly higher than any other natural fibers ever investigated. The high cellulose content and lower lignin content ensure better mechanical strength. Thus this characterization results firmly confirms the possibility of using this fiber for the manufacture of sustainable fiber reinforced polymer composite.

\section{REFERENCES}

1. Bledzki, AK. Gassan.( 1999), J Composite reinforced with cellulose base fibers, Progr Polym Sci; 24, 224-74.

2. Bolton, J. (1995). The Potential of Plant Fibres as Crops for Industrial Use. Outlook Agric, 24, 8589.

3. Satyanarayana, K. G., K. Sukumaran, P. S. Mukherjee, C. Pavithran and S. G. K. Pillai. (1990), Natural Fiber-Polymer Composites, J. Cement and Concrete Composites, 12(2) pp. 117-136. 
4. Satyanarayana, K.G., Sukumaran, K. Kulkarni, A.G., Pillai, S.G.K. andRohatgi, P.K. (1986). Fabrication and Properties of Natural Fiber-reinforced Polyester Composites , Composties , 17: 329-333

5. Gowda, T. M. Naidu, A. C. B. Chhaya, R. (1999) Some Mechanical Properties of Untreated Jute Fabric-Reinforced Polyester Composites, Journal of Composites Part A: Applied Science and Manufacturing, 30(3), pp. 277-284.

6. Antich, A. Vázquez, I. Mondragon and C. Bernal (2006). Mechanical behavior of high impact polystyrene rein forced with short sisal fibers, Composites Part A, 37, 2006, 139-150.

7. Thi-Thu-Loan Doan, Shang-Lin Gao, Edith Mäder (2006). Jute/polypropylene composites I. Effect of matrixodification Composites Science and Technology, 66, 7-8, 952-963

8. P. Pradeep, J. Edwin Raja Dhas. Tensile and Flexural Characteristics of Palm/Glass Sandwiched Polymer Composite. Journal of Mechanical and Mechanics Engineering. 2015. 1.3. 1-9.

9. N Gupta, B. S Brar Woldesenbet, (2001) Effect of filler addition on the compressive and impact fiber reinforced epoxies. Bulletin of Materials Science, Vol. 24. 2, 219-223.

10. Valadez, GA Cervantes, U Olayo, R Herrera-Franco, P.(1999) Chemical modification of henequen fibers with an organosilane coupling agent. Composites B; 30, 321-31.

11. Jensena, R.E., Palmeseb, G.R. Mcknighta,. S.H.(2006). Viscoelastic properties of alkoxy silaneepoxy interpenetrating networks. Int. J. Adh. Adhes; 26(1-2), 103-15.

12. Herrera-Franco A. Valadez-Gonza'lez, (2005) A study of the mechanical properties of short natural-fiber reinforced composites, Composites: Part B, 68, 597-608

13. P. Pradeep, J. Edwin Raja Dhas. Investigations on Alkali Treated Natural Fiber Reinforced Polymer Composite by Finite Element Analysis. Journal of Mechanical and Mechanics Engineering. 2015. 1. 1-13.

14. Ramesh, M. Palanikumar, K. Hemachandra Reddy K. (2013).Mechanical property evaluation of sisal-jute-glass fiber reinforced polyester composites, Composites Part B: Engineering, Volume 48, Pages 1-9.

15. Sreekala, Jayamol George, Kumaran, M. G. Sabu Thomas,(2002) The mechanical performance of hybrid phenol-formaldehyde-based composites reinforced with glass and oil palm fibres, Composites Science and Technology, 623,339-353

16. Pradeep, P., Edwin Raja Dhas, J. Evaluation of Mechanical Property on Palm/Coir Based Polymer Matrix Composites. Advances in Materials Science and Engineering: An International Journal. 2015. 2. 9-16.

17. Shanmugam, D. Thiruchitrambalam M. (2013).Static and dynamic mechanical properties of alkali treated unidirectional continuous Palmyra Palm Leaf Stalk Fiber/jute fiber reinforced hybrid polyester composites, Materials \& Design, Volume 50, Pages 533-542.

\section{Authors}

P.Pradeep is currently pursuing his Ph.D. in Mechanical Engineering Department ; Noorul Islam University - Thuckalay. He started his teaching career since 2006 onwards.

Dr. J. Edwin Raja Dhas is the Professor \& Head. of Automobile Engineering Department; Noorul Islam University -Thuckalay. He started his teaching career since 2005 onwards.
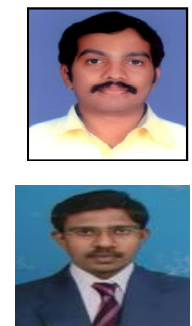